\title{
Sustainable Perspective of Electric Vehicles and Its Future Prospects
}

\author{
Pawan Maske1, Arvind Chel ${ }^{1}$, Pradeep K. Gopal ${ }^{2}$, Geetanjali Kaushik ${ }^{3 *}$ \\ ${ }^{1}$ Department of Mechanical Engineering, \\ MGM’s Jawaharlal Nehru Engineering College, Aurangabad, Maharashtra, 431003, INDIA \\ ${ }^{2}$ Department of Civil Engineering, \\ Delhi Technological University, Delhi, 110042, INDIA \\ ${ }^{3}$ Department of Civil Engineering, \\ Hi-Tech Institute of Technology Waluj, Aurangabad, Maharashtra, 431133, INDIA \\ *Corresponding Author
}

DOI: https://doi.org/10.30880/jsmpm.2021.01.01.003

Received 30 September 2021; Accepted 26 November 2021; Available online 08 December 2021

\begin{abstract}
Vehicles running on fossil fuel are creating a threat to the environment by emitting pollutants such as carbon monoxide, carbon dioxide and sulfur and nitrogen oxides into the environment. Electric vehicles and hybrid electric vehicles provide a perennial solution to this problem and since the utilization of renewables for charging, the market is on verge of electric vehicle revolution. Electric propulsion systems can also be used in heavy transport vehicles, thus transitioning them to electric. This paper puts forth an overview of the electric vehicles for transportation of masses and freight across the globe and emphasis on the battery charging infrastructures. Recent trends and advancements in electric vehicle batteries are discussed briefly, along with sustainability in Li-ion batteries and its materials; moreover, a comparative study of different electric vehicles available in the Indian market is done. Similarly, the incentives offered by government, challenges faced by these vehicles and future development areas are conversed at the end of the paper.
\end{abstract}

Keywords: Electric Vehicles (EVs), sustainability, lithium-ion batteries, charging infrastructure

\section{Introduction}

The requirements for transportation are constantly increasing due to rapid urbanization and economic development, which have led to sparking interest in the e-mobility sector. The process of carbon dioxide emission into the atmosphere is known as global warming. The gasoline-powered vehicle comprises twice the number of parts as that of electric vehicles which increases the overall carbon footprint as well [1].

Humans breathe thousands of liters of air every day, and since most of it passes through the nose, upper airway and respiratory tract, exposure to atmospheric contamination is inevitable. Pollutants can be broadly classified into two types: Primary and Secondary. Primary pollutants are the materials that are delivered into the atmosphere straightaway from the polluting source and are formed due to the combustion of fossil fuels such as Petrol and Diesel. Petrolpowered IC engines that ignite the fuel in a limited-oxygen environment produce different quantities of carbon monoxide $\left(\mathrm{CO}_{2}\right)$, nitrogen oxides $\left(\mathrm{NO}_{\mathrm{x}}\right)$, and hydrocarbons such as benzene and polycyclic aromatic compounds. While on the other hand, diesel engines blaze fuel with an excess of oxygen, which produces less carbon monoxide but more nitrogen oxides and $\mathrm{PM}_{\mathrm{x}}$ (Particulate Matter) [2]. They are responsible for respiratory tract disorders, heartbeat irregularities, and heart attacks. When primary pollutants react chemically with each other in the atmosphere they form 
Secondary pollutants. Nitric oxide (NO) generated from internal combustion engines gets converted into nitrogen dioxide, during this process it may react with the ozone layer, which reduces the atmospheric concentration. Alternatively, in the presence of sunlight in the lower levels of the atmosphere $\mathrm{NO}$ and $\mathrm{NO}_{2}$ react with oxygen $\left(\mathrm{O}_{2}\right)$ to form ozone $\left(\mathrm{O}_{3}\right) . \mathrm{O}_{3}$ is a strong oxidant and respiratory tract irritant, when inhaled by human beings causes many symptoms including shortness of breath, chest pain and other issues [3].

According to World Health Organization (WHO) air pollution is responsible for $29 \%$ of deaths and disease from lung cancer, $43 \%$ of deaths and diseases from chronic obstructive pulmonary disease, and $17 \%$ of all deaths and disease from acute lower respiratory infection. Air pollution is globally responsible for more than 4 million deaths every year [4]. According to a report by WHO the pollutants with the strongest manifestation of health issues are particulate matter $(\mathrm{PM})$, nitrogen dioxide $\left(\mathrm{NO}_{2}\right)$, ozone $\left(\mathrm{O}_{3}\right)$ and sulphur dioxide $\left(\mathrm{SO}_{2}\right)$. Table 1 shows the ambient air quality status calculated under National Air Quality Monitoring Program (NAMP) by CPCB in the year 2017 (Annual average $\left.-\mu \mathrm{g} / \mathrm{m}^{3}\right)[5]$.

Table 1 - Ambient air quality status of major cities in India [5]

\begin{tabular}{llcccc}
\hline State & \multicolumn{1}{c}{ City } & SO2 $_{2}$ & NO2 $_{2}$ & PM10 $_{10}$ & PM$_{2.5}$ \\
\hline Delhi & Delhi & 7 & 68 & 241 & 101 \\
Maharashtra & Navi Mumbai & 22 & 45 & 105 & N.A \\
Maharashtra & Aurangabad & 10 & 33 & 83 & N.A \\
Karnataka & Bangalore & 2 & 31 & 92 & 46 \\
Uttar Pradesh & Agra & 4 & 19 & 184 & 124 \\
Tamilnadu & Chennai & 9 & 17 & 62 & 32 \\
\hline
\end{tabular}

PM emitted mainly by diesel engines and other sources are inhalable and respirable, these particles comprise of sulfate, ammonia, sodium chloride, black carbon. Particles having a diameter less than 10 microns (PM10) along with fine particles less than 2.5 microns (PM2.5) pose the greatest hazard to human health, as they have the potential to penetrate human lungs and enter the bloodstream. Heavy metals comprise mainly of lead, mercury, cadmium, lithium which are sourced from lead-acid and metal hydride batteries. Even at a lower level of exposure, it can result in multiple organ damage. Fig. 1 shows PM 2.5 pollution in 5 major cities in India [6]. However due to the Covid 19 the overall pollution figures are low.
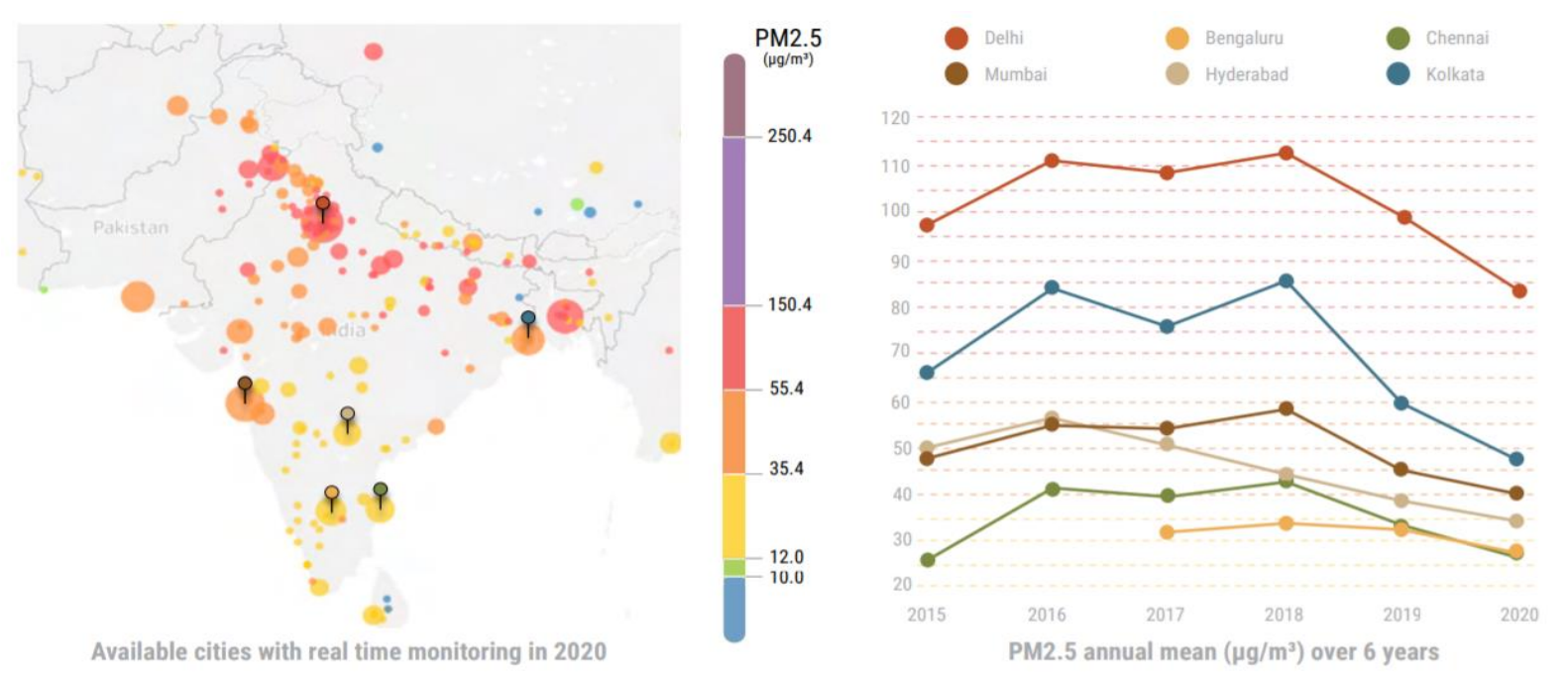

Fig. 1 - PM 2.5 pollution in 6 major cities in India [6]

E-mobility is an essential component of smart city strategies. Considerable investments are being made all across the world in EVs and charging infrastructures, which not only offers potential to reduce transport emissions, but also helps to unlock other smart city options. This includes new solutions for energy use, public transport services, residential and commercial buildings, wider urban systems, etc. Accelerating the adoption of EVs, and realizing the associated smart city benefits from it, requires coordinated and interrelated actions across a network of organizations, technologies, consumers, and products [7].

Electric vehicles have existed on the roads since the mid-19th century, but their use was limited. The latter part of the $20^{\text {th }}$ century saw a significant requirement for synthetic/alternative fueled vehicles to minimize the problems of tailpipe emissions from IC engines, increasing-price of fossil fuels, and to reduce the dependency of the countries that does not have crude oil sources within its boundaries, hence have to import foreign crude oil. It costs about a billion 
euros per day for the European economy to import of crude oil [8]. In the European continent, the transport sector is responsible for more than $30 \%$ of total energy consumption. Road transport is the largest emission emitter accounting for more than $70 \%$ of all Greenhouse Gases (GHG). The largest percentage of the emission $61 \%$ is caused by cars as shown in Fig. 2 [9].

The requirements for transportation are constantly increasing due to rapid urbanization and economic development. Which have led to sparking interest in the e-mobility sector. The process of $\mathrm{CO}_{2}$ discharged into the atmosphere diminishes the Earth's ozonosphere. A factor that makes electric vehicles clean is their ability to use half the number of parts a gasoline powered vehicle reducing the carbon footprint.

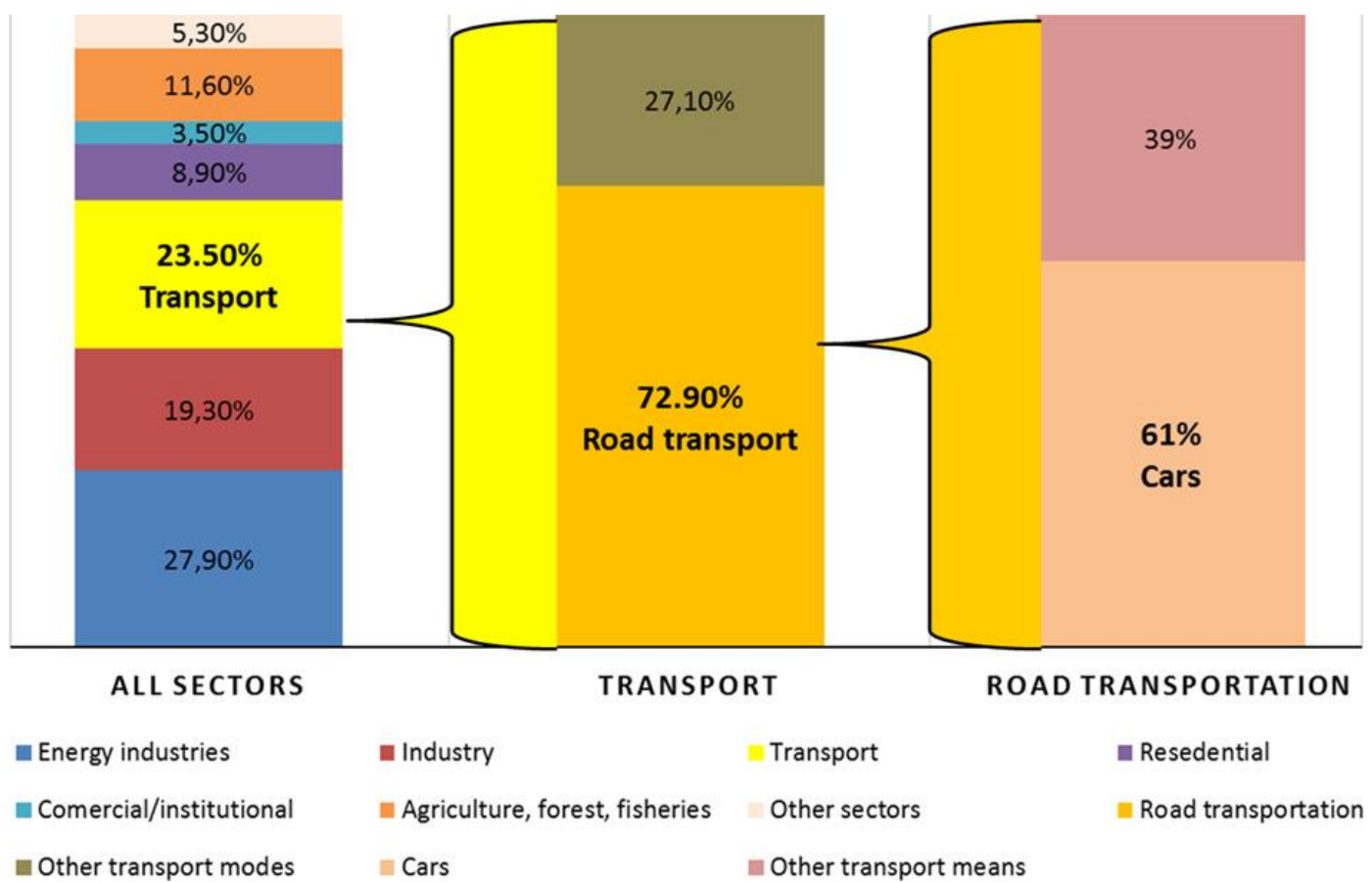

Fig. 2 - Greenhouse gas emissions by different sectors [10]

Since their re-inception in the automobile market in the start of $21^{\text {st }}$ century EV's and HEV's have started capturing the global market. With the appearance of greater stringent regulations associated with emissions, energy resource constraints and financial disaster, the world has sparked a global race to electrify transportation [11]. A collection of circumstances has contributed to electric mobility to enter the mass automotive market. Development in the renewable energy sector is one of them. All over the last decade headway in the wind and solar energy generation technologies have considerably reduced their cost. Renewables provide clean strength without any carbon footprint. The petrol, diesel and CNG needed to gas an internal combustion engine-based mobility system calls for an in-depth expensive supply chain which is prone to disruption from climate, geopolitical activities and different elements [12].

Recently, there has been massive research and development work, reported in the electric vehicle industry. Battery electric vehicles are a sustainable solution if the electricity required to power the electric power train is produced by renewable sources. Battery cells today have higher energy densities and are far less expensive per kWh than they were only a few years ago. Technological advancements in electric motors and batteries for both Electric Hybrid Vehicles [HEVs] and Electric Vehicles [EVs] have resulted in a reduction of overall production cost and increased the dependence on electric vehicles for long runs. Lithium is the best choice with regard to battery production today because of its lightweight and its high-quality electricity conductance. Recent research has shown that Li-ion batteries can withstand temperatures more than $70^{\circ} \mathrm{C}$, (in comparison to traditional batteries up to $50-60{ }^{\circ} \mathrm{C}$ ) allowing them to withstand more intensive activity with less loss of battery life. Lithium-ion (Li-ion) cells continue to receive the most investment and are the most popular. LG Chem, Panasonic, and Samsung all employ this technology. These advantages have made lithium ubiquitous in these days' energy storage industry [13]. Lithium-metal technologies with much higher energy densities are in development, but currently lack the production scale and established supply chain advantages of Li-ion [14].

The fast adoption of lithium-ion batteries in electric cars will result in a high volume of spent lithium-ion batteries in the near future, with remanufacturing, repurposing, and recycling among the alternatives for safely disposing of used lithium-ion batteries. Lithium-ion batteries are complex goods, making future recovery planning more difficult. Battery recycling, on the other hand, must be commercially feasible in order to build a truly sustainable battery sector [15]. 
Circular economy initiatives are needed at both the government and industry levels to increase the resilience and sustainability of automotive supply chains while also reducing primary resource requirements.

Electric vehicles produce fewer vibrations compared to the conventional internal combustion engine vehicles [16]. Hence it does not require a bulky frame as that of an IC engine vehicle, resulting in less overall weight. One of the superior advantages is that it does not require as much maintenance [1]. No necessities to take it to the branch of Environmental Quality for an emissions inspection. Electric vehicles are comfortable. Accordingly, the commercial electric vehicles market has seen subsequent growth in the sales. The purpose of this paper is to provide a comprehensive overview of global e-mobility; it also highlights the development and the comparison of different key components such as electric motors, batteries, electronic and controls.

\subsection{Types of Electric Vehicles (EV)}

EVs can run totally on electric powered propulsion systems. They've an Internal Combustion Engine (ICE) operating alongside it. EVs have most effective batteries as energy sources, but there are various types to rent different sources of energy modes. These may be known as Hybrid Electric Powered Cars (HEVs). Table 2 shows the differentiation of the types of electric vehicle [16-18]. Electric vehicles can be classified into the following types:

1. Battery Electric Vehicle [BEV]

2. Hybrid Electric Vehicle [HEV]

3. Plug in Hybrid Electric Vehicle [PHEV]

4. Fuel Cell Electric Vehicle [FCEV]

Table 2 - Comparison of different types of EVs

\begin{tabular}{|c|c|c|c|c|c|}
\hline $\begin{array}{l}\text { EV } \\
\text { type }\end{array}$ & $\begin{array}{c}\text { Driving } \\
\text { Component }\end{array}$ & Energy source & Feature & $\begin{array}{l}\text { Vehicle } \\
\text { Average } \\
(\mathbf{R s} / \mathbf{k m}) \\
\end{array}$ & Challenges \\
\hline BEV & $\begin{array}{l}\text { - Electric } \\
\text { powertrain }\end{array}$ & $\begin{array}{l}\text { - Batteries } \\
\text { - Ultracapacitors }\end{array}$ & $\begin{array}{l}\text { - Zerogas emission } \\
\text { - Range depends largely } \\
\text { on the type of battery } \\
\text { used } \\
\text { - Available commercially }\end{array}$ & 0.78 & $\begin{array}{l}\text { - Battery price, capacity } \\
\text { - Range per charge } \\
\text { - Charging time } \\
\text { - Availability of EV } \\
\text { charging stations } \\
\text { - High amount }\end{array}$ \\
\hline HEV & $\begin{array}{l}\text { - Electric } \\
\text { powertrain } \\
\text { - ICE }\end{array}$ & $\begin{array}{l}\text { - Batteries } \\
\text { - Ultracapacitors } \\
\text { - IC Engine }\end{array}$ & $\begin{array}{l}\text { - Less emission } \\
\text { - Long range per charge } \\
\text { - Can be powered with } \\
\text { both electricity and fuel } \\
\text { - Complex structure with } \\
\text { electrical and } \\
\text { mechanical components }\end{array}$ & 4.4 & $\begin{array}{l}\text { - Management of the } \\
\text { energy sources } \\
\text { - Battery and engine size } \\
\text { enhancement } \\
\text { - Vehicle weight }\end{array}$ \\
\hline FCEV & $\begin{array}{l}\text { Electric } \\
\text { powertrain }\end{array}$ & - Fuel cells & $\begin{array}{l}\text { - Emission tends to zero } \\
\text { - High efficiency } \\
\text { - Comparatively High } \\
\text { price } \\
\text { - Available for } \\
\text { commercial use }\end{array}$ & 1.7 & $\begin{array}{l}\text { - High cost of fuel cell } \\
\text { - Easy way to produce } \\
\text { fuel } \\
\text { - Availability of fueling } \\
\text { stations }\end{array}$ \\
\hline
\end{tabular}

\subsection{Energy Density}

Energy density is the amount of energy you can put in a certain space. According to United States Environmental Protection Agency, 1 gallon of gasoline has an equivalent of $33.7 \mathrm{kWh}$ of energy in it, which is more than the whole battery $\%$ of $1^{\text {st }}$ generation Nissan Leaf $(24 \mathrm{kWh})$. In recent years, the first-class strength density discovered in a lithium-ion battery cellular is $684 \mathrm{Wh} / \mathrm{l}$. The equal electricity by volume of 1 gallon of fuel, it would need 139 lithiumion battery cells. This means that with the aid of extent gasoline is thirteen times more energy dense than the highquality of lithium-ion batteries in 2018. Hence batteries are not space efficient [19]. Volume is important for packaging in a car. So, it makes packaging of batteries that much more difficult. Gasoline has an even larger advantage when it comes to weight. One gallon of gasoline weighs 6 pounds and has an energy density of $33.7 \mathrm{kWh}$. According to the study, the best battery pack's energy density was $240 \mathrm{Wh} / \mathrm{kg}$. The equivalent gasoline energy density was 12,400 $\mathrm{Wh} / \mathrm{kg}$, this means that gas would weigh 50 times much less than the equivalent amount of power in lithium-ion form. This assessment is about the battery cells. The battery pack might be even heavier. So, a gallon of gas has greater power in it than the original Nissan Leaf's battery pack which weighed over six hundred kilos, over 100 times heavier 
for much less energy. This makes the use of battery packs detrimental in heavier applications such as planes and trucks [20-22].

\subsection{Electric Vehicles Charging Methods}

The efficiency of a battery charger is a measure of the efficiency of the power electronics components used to convert the AC power supply to a regulated DC voltage across the battery terminals. The efficiency of the battery charger according to current technologies available worldwide varies in percentage from 70 to $90 \%$. Existing technology supports mainly three types of charging methods; however, research is being carried out on Wireless (dynamic) charging and battery swapping. According to research by Bloomberg (Fig. 3), it was found that the home charger installations have increased exponentially with the highest growth in Europe followed by China and US [23].

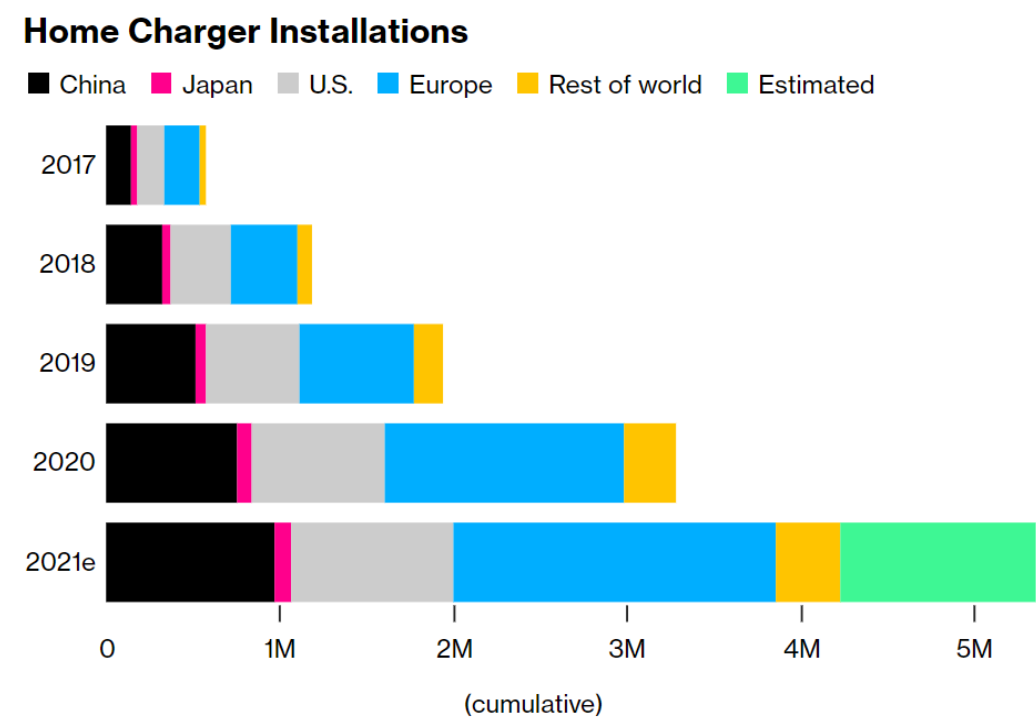

Source: BloombergNEF

Fig. 3 - Home charger installations across the world [23]

\section{(a) Level 1: AC to DC Using Onboard Charger (Normal Charging)}

The vehicle is connected to an AC power source (often $120 \mathrm{~V}$ AC with an electric input cable with a capacity of 15-20 A household load) from which the AC supply is transmitted to an onboard station charger in this charging technique. The charger's function is to convert AC to DC power and then deliver the generated current to the Li-ion battery. As a result, fully charging an electric vehicle with 30 to $40 \mathrm{kWh}$ batteries takes approximately 6-10 hours, which can be according to the domestic consumption of electrical units every month. AC to DC charging is slightly less expensive than fast charging [24].

\section{(b) Level 2: AC to DC}

The car employs three-phase Alternating Current (AC) sources of 208-240 V at up to $80 \mathrm{~A}$ in this charging mode. The Society of Automotive Engineers (SAE) has set the standard in North America the J1772 standard to cover the connector (also called coupler) and charging cable used in Level 2 changing applications as a result these charging cables are fixed permanently to Level-2 charging station. Homeowners can also install a level 2 residential charging station [25].

\section{(c) Power Charging from DC to DC (Fast Charging)}

An external charger or fast charging equipment converts the alternating current supplied by the network into a direct current with a very high voltage and power supply for use by the battery in this manner of load. A 30 to $40 \mathrm{kWh}$ EV battery can be fully charged in 60 to 90 minutes using this procedure. This approach necessitates a higher initial investment, as well as a high operating and maintenance cost, but it gives a very stable and optimal performance during peak hour demands [26].

\section{(d) Charging Via Wireless Technology}

Wireless charging has become a common charging method; yet, the charging time and effectiveness of wireless charging are still inconclusive. This charging method transmits power without any physical contact by using coupled systems magnetic fields. This technology is based on electromagnetic induction and uses two coils. The primary coil is 
installed on the road, while the secondary coil is installed inside the vehicle. The approach of dynamic wireless charging for electric vehicles is transforming the electric vehicle industry [22]. Qualcomm, a technology behemoth, is a massive supporter of dynamic charging. The FIA Formula E race series has put Qualcomm Halo WEVC technology to the test. In Auckland, Qualcomm tested the DEVC at modest speeds. The charging stations are placed in the middle of the road lanes, allowing the electric car to be charged while it is in motion. Inductive power transfer is often weak, and for efficient power transmission, the air space between the transmitter and receiver coils should be in the range of 20 to $100 \mathrm{~cm}$. Certain adjustments, however, are required before it may be used in transportation vehicles [27].

\section{(e) Battery Swapping}

A Battery Swapping Method is an efficient way of giving power to electric vehicles while avoiding excessive wait periods at a charging station. The Battery Swapping Method makes it considerably easier to integrate locally generated Renewable Energy Sources (RESs) like solar and wind. One of the key benefits of this procedure is that the drivers do not have to exit the car and can swiftly replace the drained battery. Furthermore, the station's battery can participate in the V2G (Vehicle-to-Grid) project. The Battery Swapping Stations charge the batteries ahead of time and prepare them for swapping in a short amount of time. For this strategy to function, automakers must take into account and adhere to consistent standards for the batteries of diverse EVs. As a result, car and battery makers play critical roles in battery switching technologies by collaborating together [28].

\subsection{Types of Electric Vehicles Charger}

Different chargers with different charging modes are available at the electric vehicle charging stations. These chargers are also specifically built for charging two or four-wheelers. The following are the most common and popular chargers (Fig. 4):

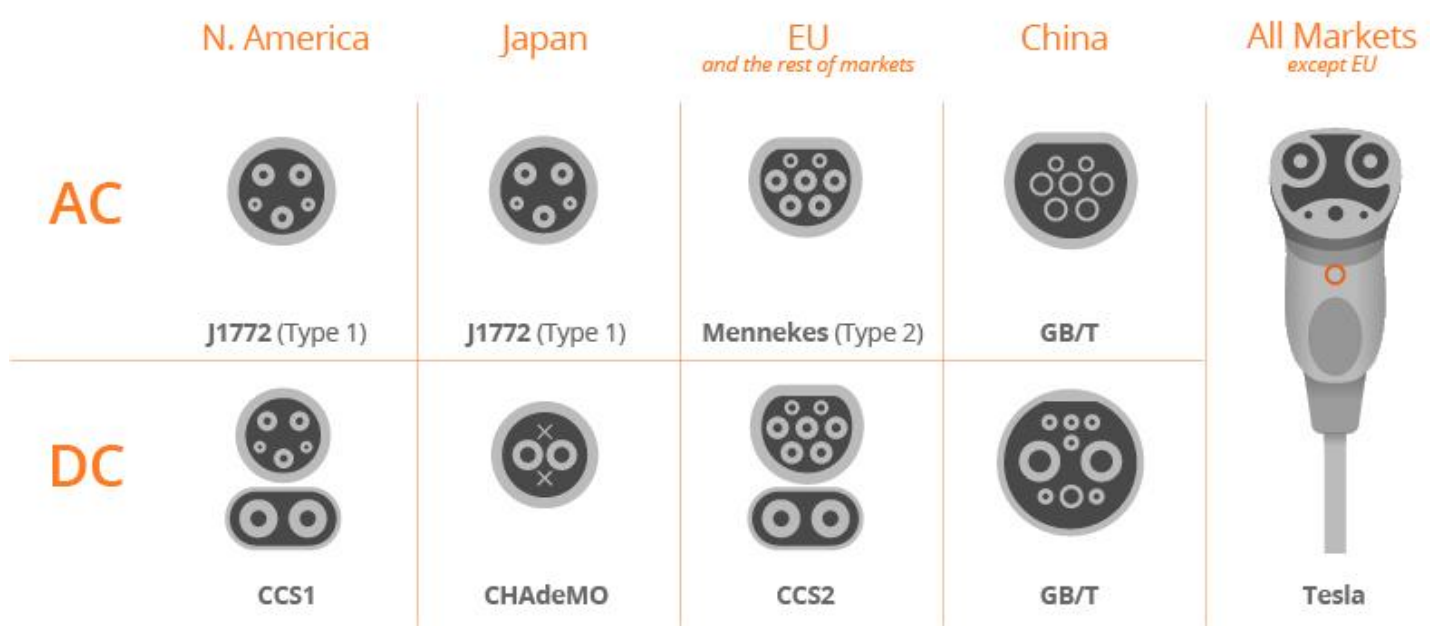

Fig. 4 - Types of electric vehicle chargers [30]

i. Combined Charging System Charger (CCS): This is one of the most common DC Fast Charging chargers. The CCS connector has Type 2 interface connections and two additional DC power lines that can handle higher voltages than the normal connector. It generates $50 \mathrm{kWh}$ of standard output power. This type of charger is estimated to cost Rs. 14 lakhs.

ii. Chademo charger: This is a traditional DC fast charger with a $50 \mathrm{kWh}$ power output. It's widely used to charge electric vehicles with four wheels. These chargers' ports are specially engineered to remain locked during the charging process. At the end of the charging time, the charge is automatically unlocked and detached from the socket. Between Rs. 13, 50, 000 and Rs. 13, 50, 000 [31] is the pricing range.

iii. Type 2 AC chargers: The IEC 62196 Type 2 AC chargers are designed to swiftly charge two-wheeled electric vehicles. It produces 22 kilowatt-hours. There are seven contact points on the connector: five large and two small. The highest row is used for Signaling. Three pins in the center row have the function of earthing, while the four pins on the outside row are used for the power supply. Two more pins are preserved as optional pins in addition to the two outside pins that can be used for power supply during rapid charging mode. It was estimated to cost around Rs. 1,200,000 [31].

iv. Bharat DC-001 charger: This charger is ARAI-certified for four-wheeler slow charging in general. It produces 15 kilowatt-hours. This charger's output has a single GB/T charging gun. The charger's output rating is 40-100 Vdc at $200 \mathrm{Amp}$ [32]. 
v. Bharat AC-001 charger: This charger is ARAI-certified for two-wheeler slow charging in general. Each of the three pins that connect to it produces $3.3 \mathrm{kWh}$ of power. This charger's output features three GB/T charging gun points. This charger will be under one lakh rupees.

\section{Global Status of Electric Vehicle}

For the first time, global new Electric Vehicle (EV) sales surpassed one million for the first time in 2017 (Fig. 5). According to future sales prediction, it is expected that the EV sales could almost four-fold that achievement by the end of 2020 , moving to 4.5 million units which is around $5 \%$ of the global light-vehicle market Figure 5 depicts the number of electric vehicles sold globally from 2010 to 2017. The need for electric automobiles is urgent [33]. BEVs presently account for 66 percent of the worldwide Electric Vehicle (EV) market. BEV sales are outpacing PEV sales (PHEV). Specific markets, on the other hand, have significantly different powertrain choices, which are determined by legislative actions, customer preferences, and model availability [23].

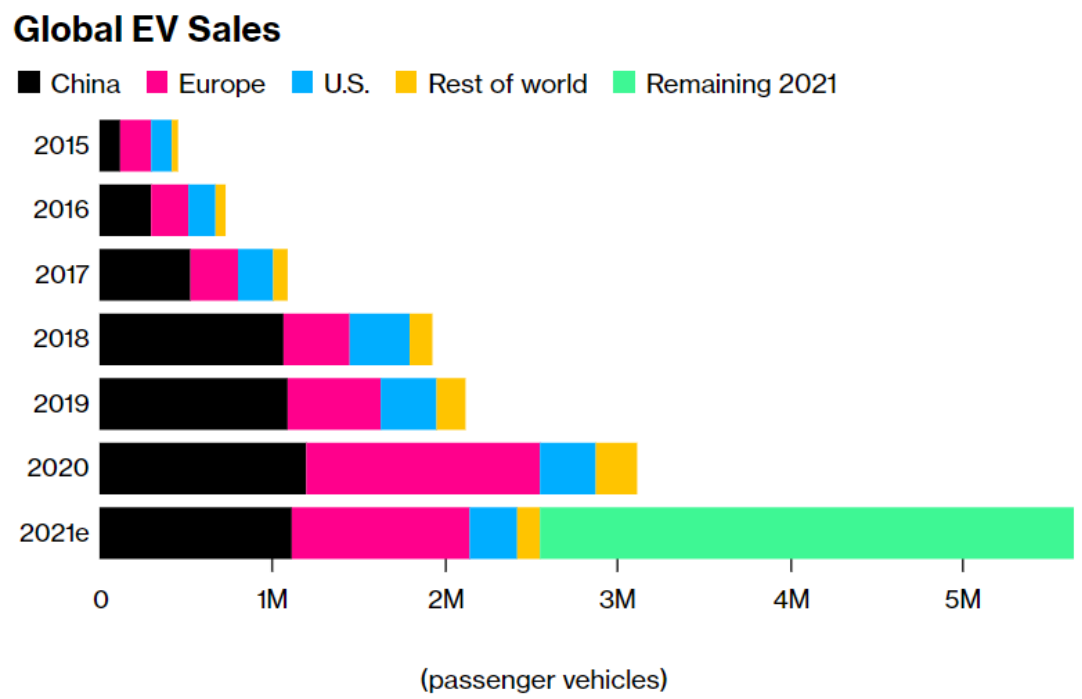

Source: BloombergNEF

Fig. 5 - Global electric vehicle sales 2015-21 [23]

China emerged as the major market for EVs. Right after Norway, China has the most electric vehicles on roads. Norway leads the world in terms of electric vehicle market share, with electric vehicles accounting for $46 \%$ of new electric vehicle sales in 2018. Not only passenger bus sales, but also electric bus sales are expected to rise, capturing 80 $\%$ of the market, as illustrated in Fig. 6. While sales of passenger cars and light commercial vehicles are expected to rise significantly [34].

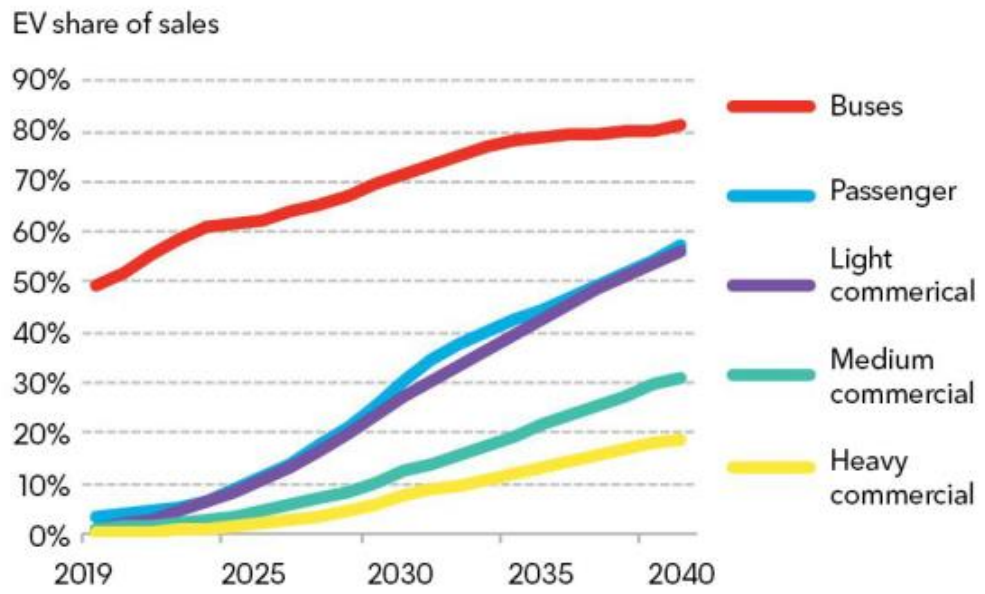

Fig. 6 - EV share of annual vehicle sales by segment [34] 
Innovations bring down the cost of production. Two-wheeler EV sectors would grow faster than the rest, especially in Asia. Escalation of EVs to spur the explosive growth of many other allied industries battery tech, advanced materials, charging infrastructure, power management software, and value-added riding services. Although there is a significant profit for emerging EV manufacturers, it possesses threat to the already existing original equipment manufacturers for IC engines. US based Tesla motors' Model S was the best-selling. Apart from electric cars automakers such as Tesla, GM cruise and Waymo are developing self-driving or autonomous vehicles. South Asian countries rely mainly on e-Rickshaws for transportation in cities. Electric three-wheelers are less expensive to operate than their gasoline-powered counterparts. As demonstrated in Fig. 7, technological developments offer a decrease in cost per km. India has 1.5 million battery-powered three-wheelers as of 2018. (Rickshaws). There are more electric rickshaws in India than battery-powered passenger automobiles in China, according to an article [34].

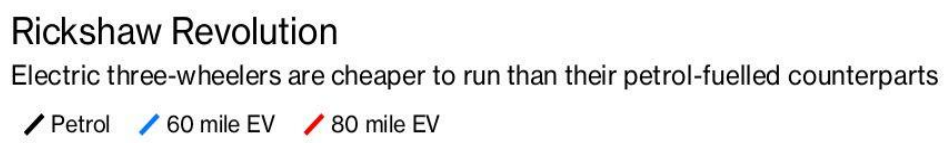

$>60$ mile EV $/ 80$ mile EV

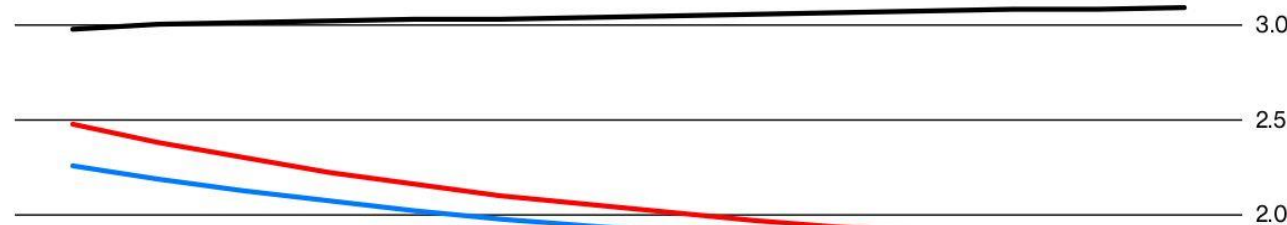

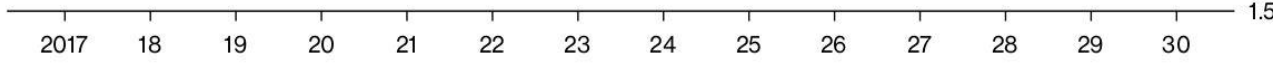

Note: shows cost in rupees per $\mathrm{km}$, in thousands of rupees

Fig. 7 - Predicted cost reduction per kilometer 2017-30 [34]

In 2015, the global electric bus fleet was predicted to be over 173,000 and by 2019 it had surpassed the 400,000 [35]. Rail vehicles (railways) have relied on overhead power wires for power in the past. In recent years, however, the Swedish heavy transportation giant Scania has teamed up with the German electrical giant Siemens to build e-highways in Sweden, where overhead electric lines are provided so that the vehicle can draw electrical power via a pantograph power collector mounted on the frame behind its cab, as shown in Fig. 8 [36]. This technology is called conductive electrical transmission.

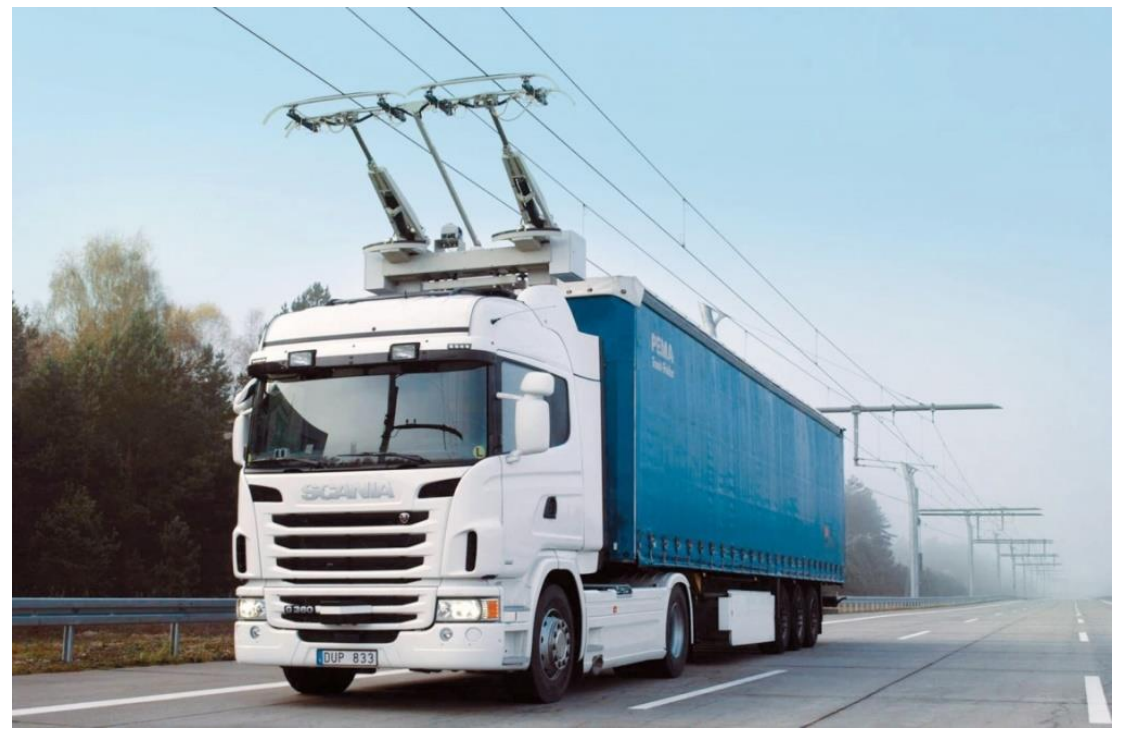

Fig. 8 - Scania truck on e-highway in Sweden [36] 
The worldwide transportation business is still dominated by fossil fuel-based mobility, but that is changing. Hybrid buses could be thought of as a first step toward full electrification. In North America, through 2020, hybrid buses will account for $73 \%$ of the electric bus market. BEB and FCEB will have a market share of $8 \%$ and $19 \%$, respectively, of the total market [37]. Shenzhen in China has the highest number of electric buses on road; typically, more than half of the cost of the BYD K9 Bus (which is around 257,920 dollars) is subsidized by the government. With the exception of India and Sri Lanka, no other SAARC country has attempted to test or adopt electric road mass transportation. Navi Mumbai Municipal Transport (NMMT), Mumbai Metropolitan Region Development Authority (MMRDA), Himachal Road Transport Communication, Bangalore Metropolitan Transport Corporation (BMTC), and Thane Municipal Transport (TMT) have all ordered Hybrid Electric Buses and Battery Electric Buses in India. The government of Sri Lanka wants to run electric buses in bus priority lanes under the Nationally Appropriate Mitigation Action (NAMA), Electric buses will be run in bus priority lanes, according to the government [38].

During the projection period from 2019 to 2030, the Indian electric vehicle ecosystem market is expected to grow at a robust Compound Annual Growth Rate (CAGR) of $43.13 \%$, according to the study. Establishing new charging infrastructure is also predicted to expand at a $42.38 \%$ CAGR. The Indian electric vehicle battery market is predicted to develop at a CAGR of $60.15 \%$ with the introduction of Indian battery producers such as TATA Chemicals and Bharat Heavy Electricals Limited (BHEL), as well as the import of batteries from foreign manufacturers [39]. In India, the most popular electric automobiles are listed in Table 3, with sample statistics that may vary.

Table 3 - Sample data for electric cars in Indian market as per manufacturers

\begin{tabular}{|c|c|c|c|c|c|c|c|}
\hline Type & $\begin{array}{c}\text { Range } \\
(\mathbf{k m})\end{array}$ & Chargers available & $\begin{array}{c}\text { Battery type } \\
\text { and capacity } \\
(\mathrm{kWh}) \\
\end{array}$ & $\begin{array}{c}\text { Motor } \\
(\mathbf{k W}, \mathbf{N m})\end{array}$ & $\begin{array}{c}\text { Battery } \\
\text { warranty } \\
\text { (year) } \\
\end{array}$ & $\begin{array}{l}\text { Cost } \\
\text { (Rs.) }\end{array}$ & $\begin{array}{c}\text { Vehicle } \\
\text { weight } \\
\text { (kg) } \\
\end{array}$ \\
\hline EV-1 & 452 & $\begin{array}{l}3 \text { types } \\
\text { 1) } \mathrm{DC} 50 \mathrm{~kW} \text { Fast } \\
\text { Charger } 80 \% \text { in57 } \\
\text { min. } \\
\text { 2) } \mathrm{AC} \text { charging } \\
6 \mathrm{~h} 10 \mathrm{~min}\end{array}$ & $\begin{array}{c}\text { Li-ion } \\
\text { Polymer } \\
(39.2 \mathrm{kWh})\end{array}$ & $\begin{array}{c}\text { Permanent } \\
\text { magnet } \\
\text { Synchronous } \\
\text { motor } \\
(100 \mathrm{~kW}, \\
395 \mathrm{Nm}) \\
\end{array}$ & $\begin{array}{c}8 \text { years or } \\
1,60,000 \\
\mathrm{~km}\end{array}$ & $\begin{array}{c}23.71- \\
23.9 \\
\text { lakh }\end{array}$ & 1535 \\
\hline EV-2 & 140 & $\begin{array}{l}\text { 2 types } \\
\text { 1) } 3 \mathrm{~kW} \text { single Phase } \\
16 \mathrm{~A} \text { Charge time } \\
7 \mathrm{~h} 20 \text { min. } \\
\text { 2) } 10 \mathrm{~kW} 3 \text { Phase } 32 \mathrm{~A} \\
\text { charge time } 1 \mathrm{~h} 35 \\
\text { min }\end{array}$ & $\begin{array}{l}\text { Lithium-ion } \\
\text { battery } \\
(15 \mathrm{kWh})\end{array}$ & $\begin{array}{c}3 \text { phase AC } \\
\text { Induction motor } \\
(19 \mathrm{~kW}, 70 \mathrm{Nm})\end{array}$ & $\begin{array}{l}3 \text { years or } \\
60,000 \mathrm{~km}\end{array}$ & $\begin{array}{l}7.48- \\
8.23 \\
\text { lakh }\end{array}$ & 937 \\
\hline EV-3 & 181 & $\begin{array}{l}2 \text { types } \\
\text { 1) Fast charging- Full } \\
\text { charge in } 1 \mathrm{~h} \\
30 \text { min. } \\
\text { 2) } \begin{array}{l}\text { Home Charging- } \\
100 \% \text { charge } \\
11 \mathrm{~h} 30 \mathrm{~min}(16 \mathrm{~A})\end{array}\end{array}$ & $\begin{array}{l}\text { Lithium-ion } \\
\text { battery } \\
(21.2 \mathrm{kWh})\end{array}$ & $\begin{array}{c}3 \text { phase } \mathrm{AC} \\
\text { Induction motor } \\
(31 \mathrm{~kW} \text { and } 91 \\
\mathrm{Nm})\end{array}$ & $\begin{array}{c}3 \text { years or } \\
1,25,000 \\
\mathrm{~km}\end{array}$ & $\begin{array}{l}10.5- \\
13.2 \\
\text { lakh }\end{array}$ & 1265 \\
\hline EV-4 & 340 & 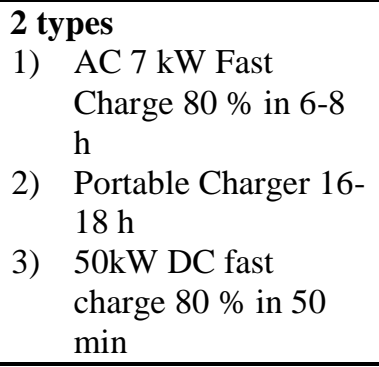 & $\begin{array}{l}\text { Ultra-high- } \\
\text { density } \\
\text { liquid-cooled } \\
\text { Nickel } \\
\text { Manganese } \\
\text { Cobalt battery } \\
(44.5 \mathrm{kWh})\end{array}$ & $\begin{array}{c}\text { Permanent } \\
\text { magnet } \\
\text { Synchronous } \\
\text { motor with } \\
(105 \mathrm{~kW} \text { and } 353 \\
\mathrm{Nm})\end{array}$ & 5 years & $\begin{array}{c}20.88- \\
23.58 \\
\text { lakh }\end{array}$ & 1539 \\
\hline EV-5 & 213 & 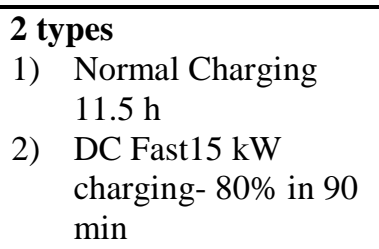 & $\begin{array}{l}\text { Lithium ion } \\
(21.5 \mathrm{kWh})\end{array}$ & $\begin{array}{c}3 \text { phase AC } \\
\text { Induction motor } \\
(30 \mathrm{~kW}, 105 \\
\mathrm{Nm})\end{array}$ & $\begin{array}{c}3 \text { years or } \\
1,25,000 \\
\mathrm{~km}\end{array}$ & $\begin{array}{l}9.54- \\
9.85 \\
\text { lakh }\end{array}$ & 1126 \\
\hline
\end{tabular}




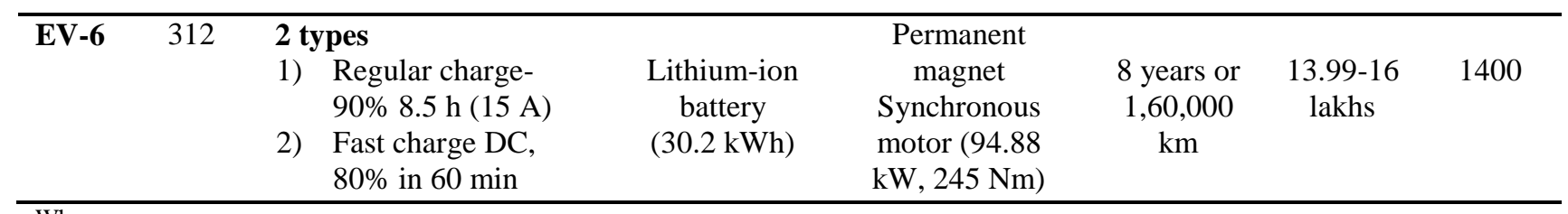

Where;

$$
\begin{aligned}
& \text { EV-1 Variants of EVs similar to Kona Electric by Hyundai } \\
& \text { EV-2Variants of EVs similar to e2o plus by Mahindra } \\
& \text { EV-3 Variants of EVs similar to e-Verito by Mahindra } \\
& \text { EV-4 Variants of EVs similar to ZS EV by MG Motor } \\
& \text { EV-5 Variants of EVs similar to Tigor EV } 2019 \text { by Tata Motor } \\
& \text { EV-6 Variants of EVs similar to Nexon EV } 2020 \text { by Tata Motor }
\end{aligned}
$$

\section{Hurdles in Development of Electric Vehicles and Their Potential Solution}

\subsection{High Cost of EVs}

(a) Provide Tax Incentives for Buying New Electric Vehicles

By lowering the purchase price of electric vehicles, financial incentives and concessions stimulate demand [26,50].

The European Union has enacted a number of major initiatives aimed at increasing electric vehicle sales. Local, regional, and national incentives, such as lower taxes or free public parking for electric vehicles, are used by the EU to promote electric mobility. They also provide funding in the form of no-strings-attached grants from the Connecting Europe Facility for the expansion of charging infrastructure, support from the EU's Horizon 2020 or the European Investment Bank for projects aiming on research and innovation in electric mobility, and incentives to encourage the purchase and use of electric vehicles [40].

Norway exempts newly purchased electric vehicles from most taxes and offers a variety of privileges, including free or subsidized parking, recharging, and access to expressways, ferries, and tunnels [41]. China has concentrated on lowering foreign investment requirements in the automotive industry in order to develop a more serious and competent market for Chinese manufacturers. China has recently introduced a double credit administrative structure that rewards or punishes manufacturers based on their car models' fuel consumption and driving range [42]. The Korean government provides a number of incentives for EV owners to boost their EV offering. Some of the incentives include a $50 \%$ decrease in highway use costs, savings on public parking, exemption from the power base price, and a reduction in the fast-charging rate. Furthermore, the government intends to maintain incentives for hydrogen and electric vehicles until $2022[43]$.

In Germany, electric vehicles and plug-in hybrids are exempt from the annual circulation tax for a duration of five years after registration. The German government offers 4,000 Euros in environmental benefits for BEVs and FCEVs, and 3,000 Euros for PHEVs [44]. The Indian government launched the Faster Adoption and Manufacturing of Electric Vehicles (FAME) Scheme, which offers incentives of up to 1.38 lakhs in addition to tax breaks for electric car purchases [45]. This scheme's Phase I lasted from 2015 to 2019, while Phase II began in 2019 and will be finished in $2022[46]$.

\section{(b) Reduce Battery Ownership Risk}

EV batteries may need to be replaced as they are susceptible to long-term wear and tear from frequent charging cycles. The cost of a replacement, on the other hand, may deter buyers from acquiring EVs [47]. Warranties, leases, and buy-back guarantees can all help to alleviate this fear. Battery guarantees ensure that if a battery fails after a certain amount of time, it will be replaced for free. These models function because even drained batteries have a residual value that can be recycled or used for other purposes. Tesla and Nissan, for example, provide battery guarantees for their electric vehicles [48]. However, warranties are sometimes limited in scope, thus extended warranty coverage funded by the government could strengthen the argument for EVs [49].

\section{(c) Provide Non-Financial Motivation}

While numerous conversations of EVs center on lessening the cost, some of the non-financial incentives can encourage EV use too. Offering free parking or reserving parking spots for EV owners is one such strategy, particularly in urban areas where parking is scarce. Another idea is to allow EV drivers to use HOV (High-Occupancy Vehicle) lanes without paying a toll, especially in cities with significant traffic congestion.

\section{(d) Public Investments in Research \& Development}

Because batteries account for the majority of the cost of an electric vehicle, the cost of manufacturing one can be reduced by investing in research and development of new battery technologies that will lower the cost and increase the efficiency of batteries, making them more affordable to consumers. Research would be required for developing state of the art electric motors and controllers, EV chargers, Active and passive safety systems, electronic power brakes, 
Component failure indication systems, electrical air-conditioners, DC-DC converters, vehicle control and battery management systems and communication protocols [12].

(e) Upgrade Government Fleets to PEVs and Encourage EV Cabs, Commercial Transport Vehicles

Government fleets can be converted to electric vehicles, boosting local EV sales. Fleet purchases not only help local EV firms, but they also demonstrate the benefits of EVs to consumers who may have been reticent to adopt them earlier. Government-run public transportation buses should be replaced with electric buses. The Municipal Corporation of Mumbai, for example, has recently added Electric buses and Fuel Cell buses to their local public transportation fleet.

\subsection{Limited Charging Infrastructure}

(a) Invest in the Installation of EV Chargers in Public Spaces and Offer Incentives for Chargers Installation

The current estimated market value of charging systems for EVs is about two billion Dollars; by the end of 2025, it is expected to grow five times the current market to 9.9 billion Dollars. While lower-cost, higher-efficiency batteries are critical for making EVs cost-competitive, many industries experts regard charging infrastructure as a major roadblock to the market's growth. EVs may easily be charged at home, but the issue arises when traveling great distances. The highways must be equipped with a variety of charging stations. In urban and suburban regions, petrol and diesel fuel stations can be found every few kilometers, and even the most distant communities have a fuel station. Only large metropolitan areas often have public EV infrastructure. Furthermore, because electric vehicles have a shorter range than gasoline vehicles, a dense charging infrastructure that can support both long and short-distance travel will be required. Only four nations account for $76 \%$ of the EU's charging stations: the Netherlands, Germany, France, and the United Kingdom. The number of electric cars charging facilities per 100 kilometers is shown in Fig. 9 [50]. The Ministry of Heavy Industries and Public Enterprises of India recently approved 2636 electric vehicle charging stations under the FAME India Phase-II Scheme [51]. According to the Chinese National Energy Administration, the government plans to install around 12,000 charging stations and 4.8 million distributed charging heaps by 2020 to meet the country's goal of 5 million electric vehicles [52]. Battery swapping has been suggested from the 1st day of the promotion of EV where batteries are not possessed by the users instead, they are provided on a rental arrangement [43]. The consumers go to charging stations to swap the drained batteries with the charged ones; hence the time needed is just a few minutes. The design of the EV should be made for such changes [53].

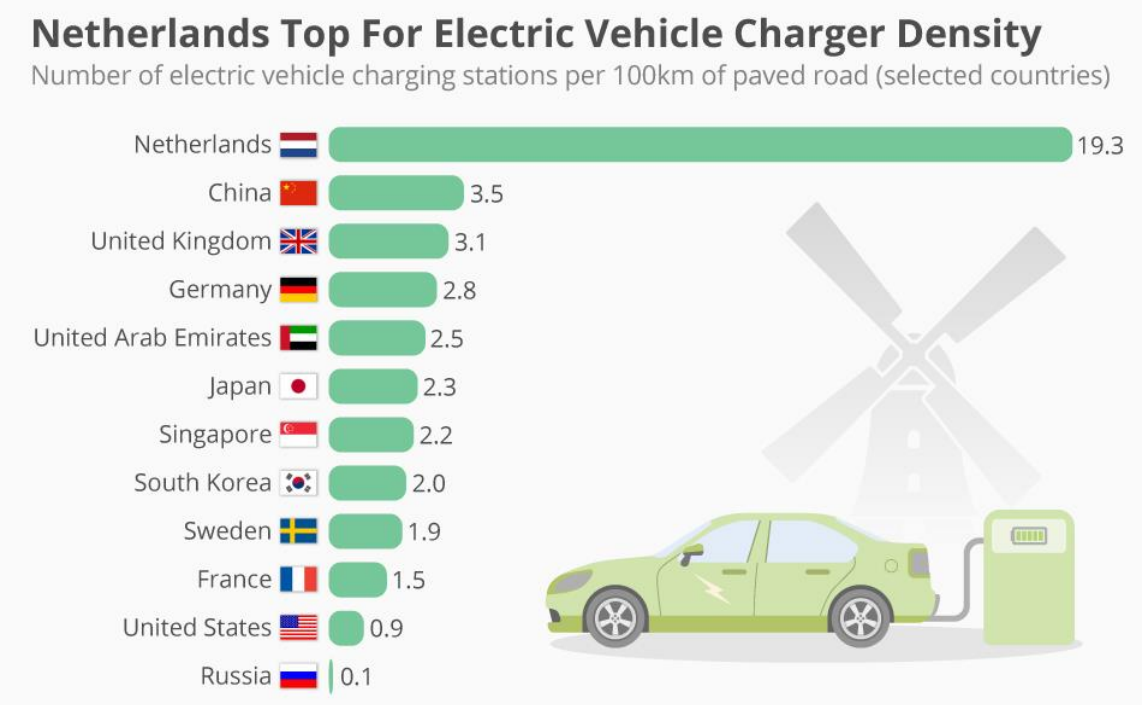

Fig. 9 - Number of electric vehicles charging stations per $100 \mathrm{~km}$ [50]

Moreover, the government can introduce some mobile applications to track the charging stations to locate EV charging stations across the country and provide reservations or booking for different charging time slots for individual.

\section{(b) Collaboration with Private Charging Stations}

Several private firms are currently building charging infrastructure, including Charge Point, e-On, and Innogy. Alternative (renewable) energy sources can be used to meet the energy requirements. The charging station industry is drawing technology behemoths such as ABB, BP, and Siemens to invest. Shell also appears to be interested in entering the electric vehicle charging industry, which it is doing through its business unit, which it purchased earlier this year [51]. In future, public-private initiatives are projected to increase. 


\section{(c) Publicize Information on Charger Locations}

Although many EV manufacturers install the locations of fast-charging stations in the vehicles' system, so that the locations can be accessed via electronic LED display, still there is a need of publicizing the information, to make the EV owners as well as prospective customers aware of the locations sessions in making sure the public is aware of charging station locations is just as vital as having the stations erected in the first place for decreasing range anxiety. Many EV manufacturers have teamed up with Google Maps to create charging maps that are consistent and up to date. EV owners merely need to search for charging stations in their neighborhood, and Google Maps will show them where they can find them. Additionally, it is now possible to schedule a Charging Slot for the required amount of time [54].

\subsection{Consumer Misperceptions}

Though hands on experience with EVs changed the attitude of many prospective buyers to a large extent, yet there is a large group of people which are adhered to conventional ICE vehicles due to certain misperceptions. While early adopters are willing to explore and appreciate the environmental and overall economic benefits of EVs, widespread adoption of EVs will necessitate addressing common customers' concerns and reservations [54]. The monetary improvement methodologies discussed above help to reduce concerns and misperception effectively. Building a buyer training program, on the other hand, is crucial for disseminating the most recent advancements in overcoming obstacles and eliminating EV fallacies. Consumer education plans should be created with the target audience in mind, and the most obvious target audience is the general public. There are a few existing assets for first-time purchasers from which monetary designers can attract data to pick up the information about the lacking side of EVs. Fig. 10 shows the paramount factors considered by the prospective EV buyers [48].

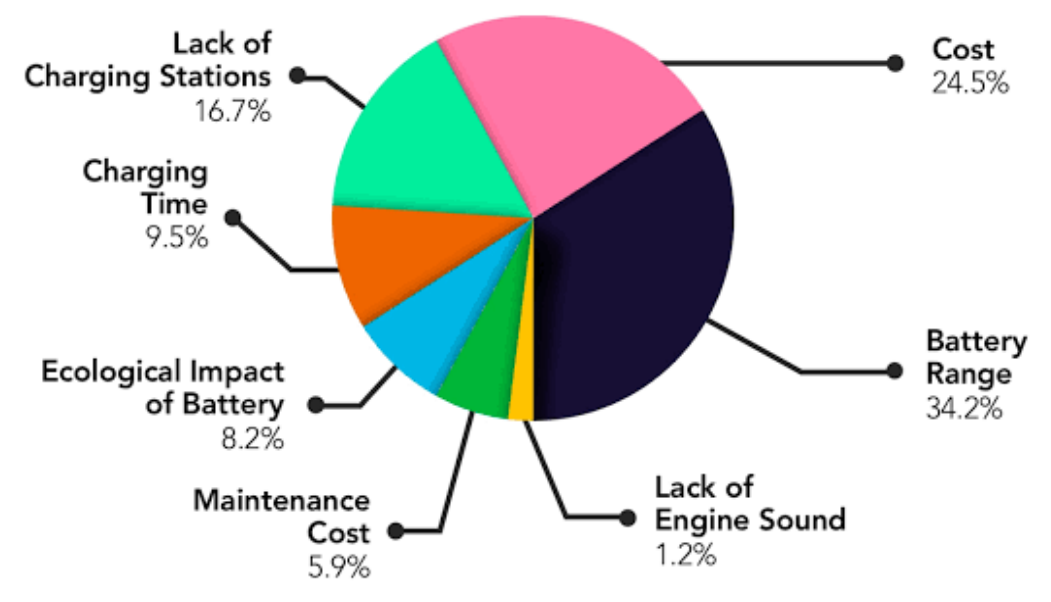

Fig. 10 - Paramount factors influencing the prospective EV buyers [48]

The adoption of electric vehicles has aided the advancements and development in both vehicles and power systems. Future research will focus on making electric vehicles more inexpensive and efficient, as well as energy management systems and increased range [55]. Following are some of the research trends:

- Better battery technology is necessary to take electric vehicle technology further. For example: Ultracapacitors and Lithium-air batteries could help increase the range of vehicles. Prolonging battery life is an additional area for improvement [56].

- Battery charging technologies such as dynamic wireless charging will gain tremendous focus by researchers. Ultra-fast charging will be an area of improvement resulting in minimization of charging time [27].

- Overhead power supply (conductive electrical transmission) can be considered as a solution for heavy freight carrier trucks which follow a designated route. Such practical research is being carried out on highways of Sweden by Siemens and Scania [36].

- Vehicle to Grid (V2G) allows energy to be delivered back to the power grid from an electric car's battery and then retrieved when needed. This technology will produce incredible achievements in the field of energy management [57].

- Hydrogen fuel cell cars can be a part of military and defense applications in the future. There is a scope of research in methods used for obtaining hydrogen from the air. 


\section{Mitigation of Air Pollution Due to Electric Vehicles}

Adoption of the electric car to mitigate air pollution and climate change is currently burning issue. Human beings have become vulnerable to Lung cancer, respiratory infections and heart diseases. Not only humans but the emission of $\mathrm{CO}_{2}$, Sulphur oxides, Nitrogen oxides and particulate matter in air is a major concern for the environment too. Although bio-diesels and CNG vehicles create less pollution; electric vehicles are far more efficient than its market competitors such as Conventional ICE cars and compressed air-powered cars [58,59].

In research, one of the key results was obtained for $20 \%, 50 \%$ and $100 \%$ IC engine vehicle substituting with Electric vehicles, the total petrol production reduces by $6.65 \%, 16.62 \%$ and $33.24 \%$, on the other hand, the total electricity production will increase by $2.82 \%, 7.05 \%$ and $14.10 \%$ [60]. An ICE vehicle dispenses $\mathrm{CO}_{2}$ and other pollutants during car manufacturing, petroleum production and from the tailpipe in its total life cycle. On the other hand, Electric vehicles do not have any exhaust emissions. Moreover, if the electricity production is from low or non$\mathrm{CO}_{2}$ emitting sources such as renewable sources which are responsible for decarbonization, then the only source of $\mathrm{CO}_{2}$ production is car manufacturing and supply chain as shown in the Fig. 11 [61].

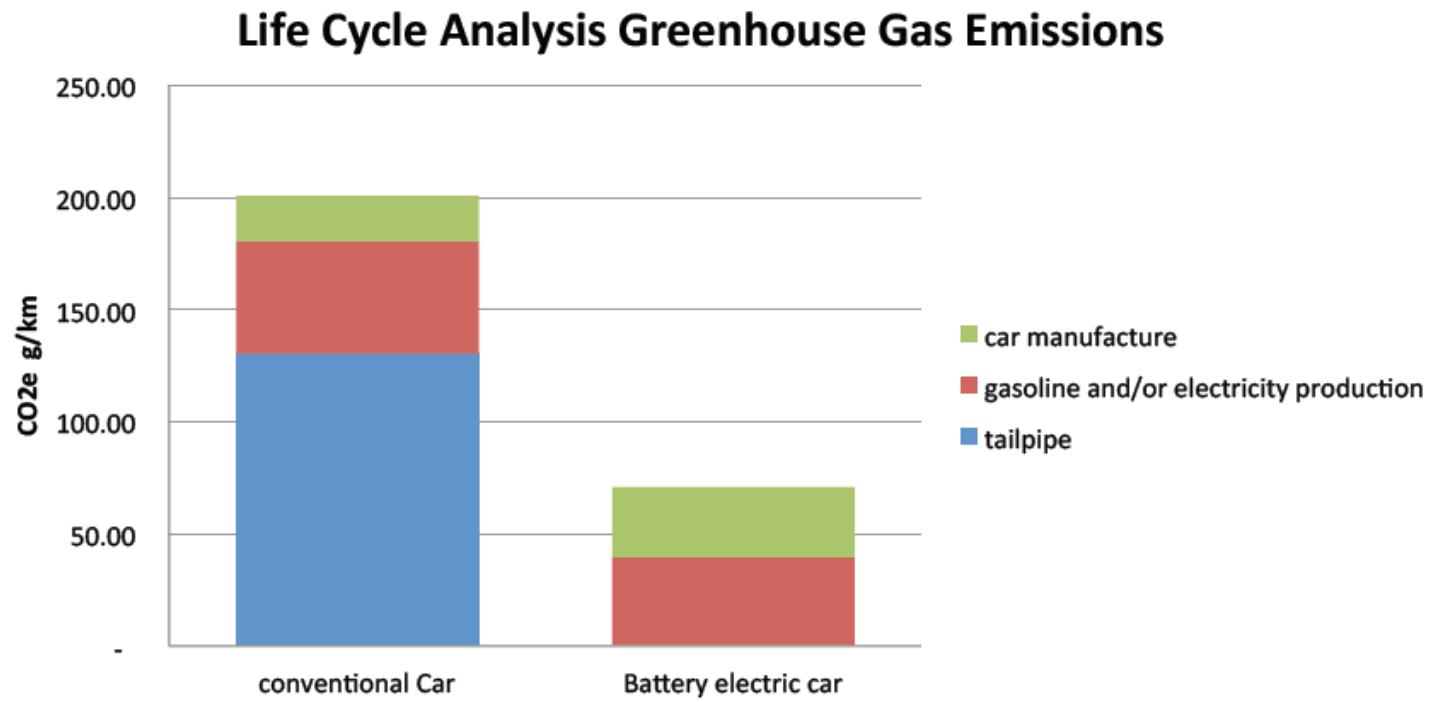

Fig. 11 - Life cycle analysis of $\mathrm{CO}_{2}$ emission in Canada [58]

In accordance with a report issued for the state of Minnesota by MCPA, EVs could significantly improve air quality especially in the areas with busy roadways by reducing not only the carbon emission but also the $\mathrm{NO}_{\mathrm{x}}$ and particulate matter as shown in the Fig. 12 [61].

\section{Annual vehicle emissions by fuel type $(12,000$ miles $)$}

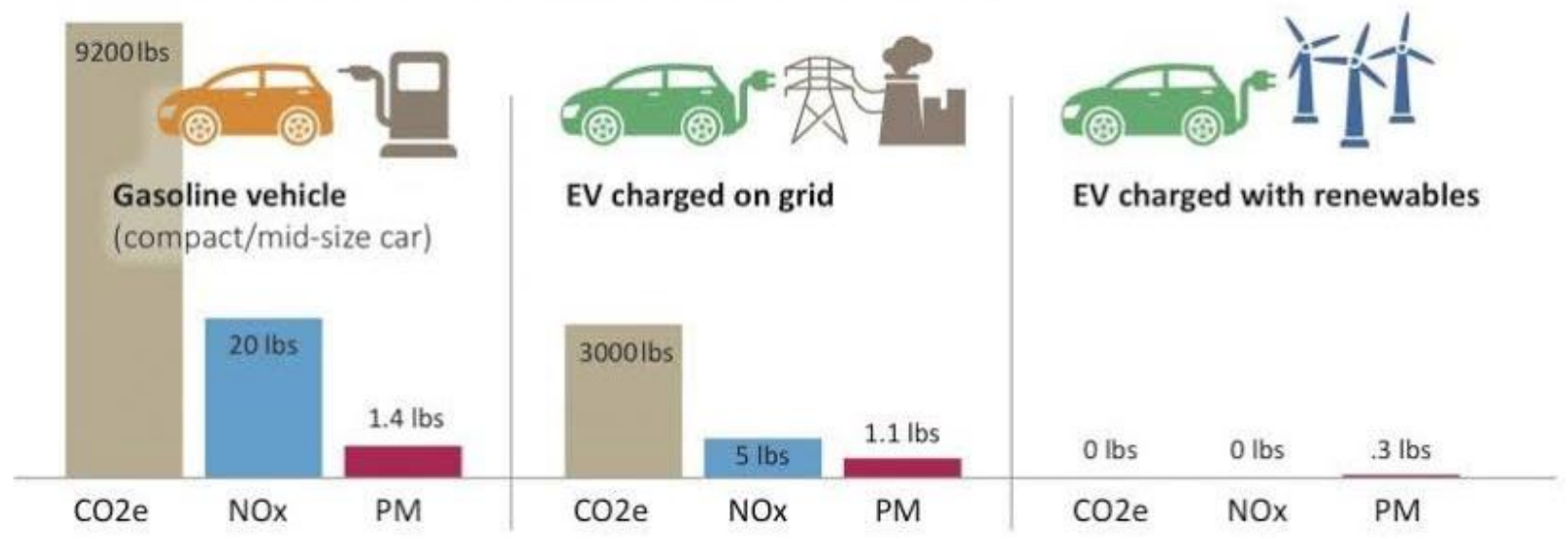

Fig. 12 - Annual vehicle emissions by fuel type in the state of Minnesota [63]

In a study to assess a scenario of electric vehicles substituting conventional gasoline-power cars in the city of São Paulo in the decade (2020 and 2030) were carried to estimate the $\mathrm{CO}_{2}$ emission and Energy consumption. It was found 
that a reduction of about 11.0 million tones $\mathrm{CO}_{2}$ by year 2030 is achievable with the transitioning of $20 \%$ of gasoline cars with battery electric cars [62].

\section{Results and Discussion}

Electric vehicles have unquestionably huge potential to become the future mode of mass and freight transportation while also protecting the world from automobile emissions that degrade outdoor air quality and contribute to global warming [62-64]. On average electric vehicles have a travel cost of Rs. 0.78 to Rs.1.2 per km which is a bit more economical as compared to the Fuel cell vehicles with a travel cost of Rs.1.7 per km. However, the hybrid electric vehicle has a travel cost of Rs. 4.4 per $\mathrm{km}$ which involves electric motor and Internal Combustion Engines. The conventional vehicles running on fossil fuels have travel costs in the range of Rs.6 to Rs.9 per km.

Based on the range and battery capacity of the EV from Table 3, an analysis was conducted for electric vehicles in India to calculate the energy required for transportation $(\mathrm{km} / \mathrm{kWh})$. Table 4 shows the anticipated travel cost (Rs./km) for EVs based on the price of power required to charge the battery (Rs.8/kWh). Based on the battery capacity and mass of the EV reviewed in Table 4, the energy density of the EV (kWh/ kg of EV) was calculated.

Table 4 - Comparison of electric vehicles in India [65]

\begin{tabular}{lccc}
\hline $\begin{array}{l}\text { Electric } \\
\text { vehicles }\end{array}$ & $\begin{array}{c}\text { Run per unit energy } \\
\text { consumption }(\mathbf{k m} / \mathbf{k W h})\end{array}$ & $\begin{array}{c}\text { Travel cost } \\
(\mathbf{R s} . / \mathbf{k m})\end{array}$ & $\begin{array}{c}\text { Energy density of the vehicle } \\
(\mathbf{k W h} / \mathbf{k g} \text { of Vehicle) }\end{array}$ \\
\hline EV-1 & 11.5 & 0.9 & 0.025 \\
EV-2 & 8 & 0.8 & 0.016 \\
EV-3 & 7.9 & 1.15 & 0.017 \\
EV-4 & 7.9 & 1 & 0.028 \\
EV-5 & 9.9 & 0.8 & 0.019 \\
EV-6 & 10.3 & 0.77 & 0.021 \\
\hline
\end{tabular}

\section{Conclusion}

In the mission to achieve the goal of smart city, we have to look at transportation and smart grid with a new and innovative approach; and since both are connected to electric vehicle adoption in the market it would be easier to achieve the Smart City Goals complemented by EV Ecosystem. We have recommended some research directions in this study that could lead to better EV migration and adoption among the masses. Electric Vehicles are viable alternatives to conventional vehicles. Especially when the energy used to charge these vehicles is produced by renewable sources.

- A tabular comparison of different types of vehicles is issued in Table 2. Followed by a sample of comparison among the few electric vehicles in the markets shown in Table 3, which are subjected to change due to updating or modifications in the EVs.

- Global overview of battery electric vehicles, Heavy Transport EVs.

- Ways to overcome the hurdles in developments of electric vehicles and charging infrastructure have been accessed.

- Mitigation of air pollution due to Electric vehicles is explained comprehensively.

- A review on Li-ion Batteries sustainable recycle process has been explained.

- $\quad$ Finally, research trends and future development areas are described.

\section{References}

[1] Argueta, A. (2010). A Technical Research Report: The Electric Vehicle.

[2] Lumb, A. B. \& Thomas, C. R. (2017). Smoking and Air Pollution. In Nunn's applied respiratory physiology 8th Edition (pp. 281-290). Elselvier.

[3] Ghosh, R. \& Hertz-Picciotto, I. (2014). The Epidemiology of Air Pollution and Childhood Lung Diseases. In The Lung (pp. 423-437). Academic Press.

[4] World Health Organization (2021). Ambient Air: Pollutant. Retrieved from https://www.who.int/airpollution/ambient/pollutants/en/

[5] Ministry of Environment and Forests (2021). National Ambient Air Quality Monitoring Programme (NAMP) Data. Retrieved from http://www.cpcbenvis.nic.in/air_quality_data.html.

[6] IQAir, (2020). 2020 World Air Quality Report: Region \& City PM2.5 Ranking.

[7] Shaikh, P. W. \& Mouftah, H. T. (2021). Intelligent Charging Infrastructure Design for Connected and Autonomous Electric Vehicles in Smart Cities. IFIP/IEEE International Symposium on Integrated Network Management. pp. 992-997 
[8] Van Mierlo, J. (2018). The world electric vehicle journal, the open access journal for the e-mobility scene. World Electr. Veh. J. 9.

[9] Ajanovic, A. \& Haas, R. (2019). Economic and environmental prospects for battery electric - and fuel cell vehicles: a review. Fuel Cells, 19, 515-529.

[10] European Commission (2017). Mobility and Transport. Retrieved from https://transport.ec.europa.eu/index_en.

[11] Song, Y., Yang, Y., \& Hu, Z. (2011). Present status and development trend of batteries for electric vehicles. Power System Technology, 35(4), 1-7.

[12] Aayog, N. I. T. I., Juyal, S., Sanjeevi, H., Saxena, A., Sharma, S., \& Singh, A. (2018). Zero emission vehicles (ZEVs): Towards a policy framework. NITI Aayog, Government of India, New Delhi, India.

[13] Lee, H., \& Clark, A. (2018). Charging the future: Challenges and opportunities for electric vehicle adoption.

[14] Marcos, J. T., Scheller, C., Godina, R., Spengler, T. S., \& Carvalho, H. (2021). Sources of uncertainty in the closed-loop supply chain of lithium-ion batteries for electric vehicles. Cleaner Logistics and Supply Chain, 1, 100006.

[15] Chen, M., Ma, X., Chen, B., Arsenault, R., Karlson, P., Simon, N., \& Wang, Y. (2019). Recycling end-of-life electric vehicle lithium-ion batteries. Joule, 3(11), 2622-2646.

[16] Gustafsson, T., \& Johansson, A. (2015). Comparison between battery electric vehicles and internal combustion engine vehicles fueled by electrofuels-From an energy efficiency and cost perspective (Master's thesis).

[17] Chan, C. C. (2002). The state of the art of electric and hybrid vehicles. Proceedings of the IEEE, 90(2), $247-275$.

[18] Gunther, P., Carstensen, F. V., Graziano, M., \& Coghlan, J. (2012). Driving Smart Growth: Electric Vehicle Adoption and Off-Peak Electricity Rates. Storrs (CT), USA: Connecticut Center for Economic Analysis.

[19] Offer, G. J., Howey, D., Contestabile, M., Clague, R., \& Brandon, N. P. (2010). Comparative analysis of battery electric, hydrogen fuel cell and hybrid vehicles in a future sustainable road transport system. Energy policy, 38(1), 24-29.

[20] Pema, T. (2019). YourStory research's in-depth report on the EV revolution - Global prospects and Indian opportunities.

[21] Tarascon, J. M., \& Armand, M. (2011). Issues and challenges facing rechargeable lithium batteries. Materials for sustainable energy: a collection of peer-reviewed research and review articles from Nature Publishing Group, 171179.

[22] Miao, Y., Hynan, P., Von Jouanne, A., \& Yokochi, A. (2019). Current Li-ion battery technologies in electric vehicles and opportunities for advancements. Energies, 12(6), 1074.

[23] Stock, K. (2021). The electric vehicle invasion is already here. BloombergNEF.

[24] Iclodean, C., Varga, B., Burnete, N., Cimerdean, D., \& Jurchiş, B. (2017). Comparison of different battery types for electric vehicles. In IOP conference series: materials science and engineering, 252, 012058).

[25] Un-Noor, F., Padmanaban, S., Mihet-Popa, L., Mollah, M. N., \& Hossain, E. (2017). A comprehensive study of key electric vehicle $(\mathrm{EV})$ components, technologies, challenges, impacts, and future direction of development. Energies, 10(8), 1217.

[26] Dashora, H. D. (2017). Dynamic Wireless Charging of Electric Vehicle.

[27] Yambar, P. (2018). Dynamic wireless charging of electric vehicle. International Journal for Research in Applied science and Engineering Technology, 6(3).

[28] Qualcomm Technologies Inc. (2017). Halo Dynamic Electric Vehicle Charging.

[29] Mahoor, M., Hosseini, Z. S., Khodaei, A., \& Kushner, D. (2017). Electric vehicle battery swapping station. arXiv preprint arXiv: 1710.06895 .

[30] Maske, P., Agrawal, M., \& Chel, A. (2020). Design of braking system for an electric golf-cart. International Journal of Research and Analytical Reviews, 7(1), 868-873.

[31] JuiceBlog (2019). The different ev charging connector types.

[32] Cui, Q., Weng, Y., \& Tan, C. W. (2019). Electric vehicle charging station placement method for urban areas. IEEE Transactions on Smart Grid, 10(6), 6552-6565.

[33] Okaya Power Bharat Charger Specifications (2021). Retrieved from https://okayapower.com/pdf/Bharat-AC-EVCharger.pdf

[34] Bloomberg electric vehicles outlook (2019). Retrieved from https://about.bnef.com/electric-vehicle-outlook/

[35] Ward, J., \& Upadhyay, A (2018). India's Rickshaw Revolution Leaves China in the Dust. Retrieved from https://www.bloombergquint.com/business/india-s-rickshaws-outnumber-china-s-electric-vehicles

[36] Sustainable-Bus Editorial (2020). Electric bus, main fleets and projects around the world.

[37] Automotive World Ltd. (2013). Scania and Siemens to develop electrically powered vehicles.

[38] Mahmoud, M., Garnett, R., Ferguson, M., \& Kanaroglou, P. (2016). Electric buses: A review of alternative powertrains. Renewable and Sustainable Energy Reviews, 62, 673-684.

[39] PwC (2018). Deployment of electric road mass transportation in South Asia SAARC Energy Centre.

[40] BIS research (2019). Emerging Technology Market Intelligence. Retrieved from https://bisresearch.com/industryreport/india-electric-vehicle-market.html 
[41] International Energy Agency (2018). Global EV Outlook 2018. Retrieved from https://www.iea.org/reports/global-ev-outlook-2018

[42] Knudsen, C. \& Doyle, A. (2018). Norway powers ahead (electrically): over half new car sales now electric or hybrid.

[43] Diying, W. (2019). Leading international electric vehicle policies: success stories of Norway and China.

[44] Nikola (2019). Electric cars in Korea. KOJECTS.

[45] Federal Ministry of Economic Affairs and Energy (2020). Electric Mobility. Regulatory environment and incentives for using electric vehicles and developing a charging infrastructure.

[46] PTI (2015). FAME-India scheme launched to offer sops on hybrid, e-vehicles. The Economic Times.

[47] Department of Heavy Industry (2021). Retrieved from https://dhi.nic.in/

[48] Todd, J., Chen, J., \& Clogston, F. (2013). Creating the clean energy economy. analysis of the electric vehicle industry. International Economic Development Council, Washington, DC.

[49] Tesla, Inc. (2017). Model S. Retrieved from https://www.tesla.com/models

[50] EDF Energy (2020). All about electric car batteries. Retrieved from https://www.edfenergy.com/electriccars/batteries

[51] Niall M. (2018). Netherlands top for electric vehicle charger density. Statista.

[52] Ministry of Heavy Industries \& Public Enterprises (2020). In Phase-II to Fame India Scheme 2636 EV Charging Stations sanctioned. Retrieved from https://pib.gov.in/newsite/PrintRelease.aspx?relid=197263

[53] Cheng, K. W. E. (2009). Recent development on electric vehicles. In 2009 3rd International Conference on Power Electronics Systems and Applications (PESA) (pp. 1-5). IEEE.

[54] Yvkoff, L. (2019). With Shell's Acquisition of greenlots, big oil extends its reach Into EV infrastructure. Forbes.

[55] Taylor, M. (2018). Consumer Behavior and the Plug-In Electric Vehicle Purchase Decision Process: A Research Synthesis.

[56] Lambert, F. (2017. Tesla Model 3 to have best-in-class depreciation, report says. Electrek.

[57] Singh, K. V., Bansal, H. O., \& Singh, D. (2019). A comprehensive review on hybrid electric vehicles: architectures and components. Journal of Modern Transportation, 27(2), 77-107.

[58] Virta (2021).Vehicle to grid technology. Retrieved from https://www.virta.global/vehicle-to-grid-v2g

[59] Hill, G., Heidrich, O., Creutzig, F., \& Blythe, P. (2019). The role of electric vehicles in near-term mitigation pathways and achieving the UK's carbon budget. Applied Energy, 251, 113111.

[60] Hofmann, J., Guan, D., Chalvatzis, K., \& Huo, H. (2016). Assessment of electrical vehicles as a successful driver for reducing CO2 emissions in China. Applied energy, 184, 995-1003.

[61] Bailie, B. (2013). Clean air benefits from electric vehicles: Potential impacts of additional electric vehicles in City of Campbell River, the Peace River Region and City of Richmond. PEMBINA Institute.

[62] Smith, A. J., McMahon, C., \& Conti, B. (2017). The air we breathe: The state of Minnesota's air quality. Minnesota Pollution Control Agency.

[63] Costa, E., \& Seixas, J. (2014). Contribution of electric cars to the mitigation of $\mathrm{CO}_{2}$ emissions in the city of Sao Paulo. In 2014 IEEE Vehicle Power and Propulsion Conference (pp. 1-5). IEEE.

[64] SAE International. SAE Electric Vehicle and Plug-in Hybrid Electric Vehicle Conductive Charge Coupler. In SAE Standard J1772; Society of Automotive Engineers (SAE): Warrendale, PA, USA, 2010.

[65] Yilmaz, M., \& Krein, P. T. (2012). Review of battery charger topologies, charging power levels, and infrastructure for plug-in electric and hybrid vehicles. IEEE transactions on Power Electronics, 28(5), 2151-2169. 